\title{
ランダムおよびバースト性の一定の平均符号誤り率を有する 伝送路シミュレータの設計と特性評価
}

\author{
学生員 土屋 如右* 非会員 田中 公男**
}

\author{
Design and Characteristics Evaluation of the Transmission Line Simulator having a \\ Certain Random and Burst Average Bit Error Rates
}

Naosuke Tsuchiya*, Student Member, Kimio Tanaka**, Non-member

\begin{abstract}
In binary digital transmission, a bit error rate (BER) is the most important evaluation standard. But actual transmission line does not give any bit error rate, because a bit error occurs by existence of analog noise power. If these noisy communication channel which shows a certain random and burst bit error rate, called a transmission line simulator, can be constructed artificially, it is very useful for evaluation of data transmission quality. This paper proposes the theoretical design method of transmission line simulator using a combination of the maximum length sequence generator and binary counter circuits or two maximum length sequence generators. The feature of this proposed systems is that an average bit error rate is controlled by changing the length of shift register. The fundamental concept and its characteristics are described.
\end{abstract}

キーワード：伝送路シミュレータ, 最大長系列, 平均符号誤り率 , バーストエラー , シフトレジスタ

Keywords: transmission line simulator, maximum length sequence, average bit error rate, burst error, shift register

\section{1. まえがき}

ディジタル 2 進伝送方式においては, 通信路もしくは通 信機器から発生する雑音により符号誤りが発生し，伝送品 質に悪影響を及ぼすこととなる。これを評価する重要な尺 度が平均符号誤り率 (BER) である ${ }^{(1)}$ 。しかし，実際の伝 送路の符号誤り特性はアナログ的性質を有する加法性白色 雑音の電力量で決まることから平均符号誤り率を任意の値 に制御することはやや困難である。

通信路の符号誤り特性は, 一般的には帰還形シフトレジ スタにより発生させた擬似乱数を標準化試験信号として伝 送し，受信側で送信信号と比較して誤りを計数することに より評価される ${ }^{(2)}$ 。伝送路の平均符号誤り率が任意の一定 值に制御可能な伝送路シミュレータが実現できれば実際の 伝送路を使用することなく符号器，中継器，変復調器の特

\footnotetext{
* 東海大学大学院工学研究科電気工学専攻

T 259-1292 神奈川県平塚市北金目 1117

Graduate School of Engineering, Course of Electrical Engineering, Tokai University

1117 Kitakaname Hiratsuka Kanagawa 259-1292, Japan

** 東海大学電子情報学部コミュニケーション工学科

厂 259-1292 神奈川県平塚市北金目 1117

Department of Communications Engineering, School of Information Technology and Electronics, Tokai University 1117 Kitakaname Hiratsuka Kanagawa 259-1292, Japan
}

性を評価・解析することが容易となる。また，送信情報に 誤り訂正機能を付加して伝送し, シミュレータの平均符号 誤り率を可変とすることにより必要とする誤り訂正能力を 想定することが可能となり，伝送路設計時の一つの指針を 得ることにも利用しうる。

一定の符号誤り率を有する伝送路シミュレータを構成す る際，雑音符号系列発生源として通常の帰還形シフトレジ スタを用いると平均符号誤り率はほぼ $1 / 2$ に固定され任意 の值に制御することは不可能である。したがって，本論文 では最大長系列を発生する帰還形シフトレジスタと 2 進カ ウンタあるいは同一次数の帰還形シフトレジスタを組合せ ることにより，雑音系列の周期を単一の帰還形シフトレジ スタの周期よりも大幅に拡大するとともに , シフトレジス タの段数を可変とすることにより雑音系列の発生率，すな わち平均符号誤り率を制御しうる方法を提案するものであ る。また，本方法は簡易な構成で実現可能であること，ソ フトウェア処理よりもハードウェア構成に適していること にも特徵がある。さらに, 本方法の応用としてランダムエ ラービット発生器 2 組を用いてバースト性のエラービット を発生しうる回路構成についても提案する。

本論文の提案に類似の方法としては, アナログ雑音付加 により平均符号誤り率を制御するアナログ型シミュレータ および無線通信を対象とするフェージングシミュレータが 挙げられる。しかし, 前者は付加するアナログ雑音がゆら 


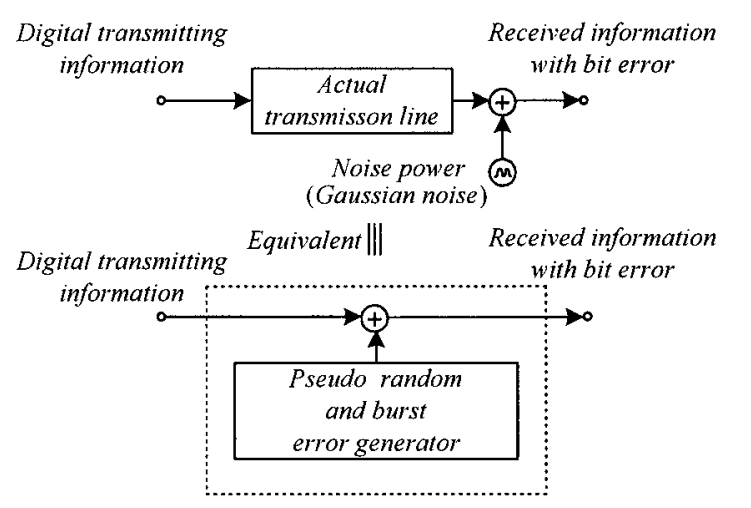

図 1 伝送路シミュレータの基本概念

Fig. 1. Basic concept of transmission line simulator.

ぎを有するため平均符号誤り率にもゆらぎを生じ光の値を 特定することは困難である。また，後者については多くの シミュレータが開発・実用化されているが，いずれもマル チパスフェージングによる伝搬路特性をアナログ的に模擬 するもので, 平均符号誤り率を制御する機能を備えている ものは見当たらない。これらに対して本方法はディジタル 的手法を用いて平均符号誤り率を確定，かつ制御しうる点 が他の手法と異なるものである。

以下には提案する本方式の基本原理と基本回路構成およ び特性解析手法と数值解析例について述へ，光の有効性を 明らかにする。

\section{2. 伝送路シミュレータの基本原理}

ディジタル情報の伝送では，伝送媒体および等化増幅器 などから発生するガウス雑音によりランダム的に符号誤り が生じる。ガウス雑音は特定の性質を有する加法性アナロ グ雑音であり，信号電力対雑音電力比により平均符号誤り 率を理論的に算出することが可能である。本シミュレータ は, これと同等の特性をデイジタル的に実現するもので, 実 際の伝送路と本論文での方法との関連を図 1 に示す。

本シミュレータの主要部分であるエラービット発生器は， 擬似ランダム系列を生成する最大長系列発生器とカウンタ 回路を, または 2 つ最大長系列発生器を組合せて構成す るもので, 簡易なハードウェアで実現でき，種々の情報伝 送に対する伝送品質の評価に貢献しうるものと思われる。 これらの方式では，入力情報系列とエラービット発生器の 出力とのビットごとの排他的論理和をとることにより符号 誤りを受けた受信情報系列が得られることとなる。

\section{3. 最大長系列発生器の基本構成}

最大長系列 (Maximum length sequence: M 系列) は人 工的にある簡単な規則に基づいて作られる確定的系列である か概観上不規則な系列に似ており擬似不規則信号 (pseudorandom signal) の一つである。一般には, 多レベルの M 系 列が存在するが，ここでは 2 レべルの M 系列を対象とする。 最大長系列発生器 (Maximum length sequence generator)

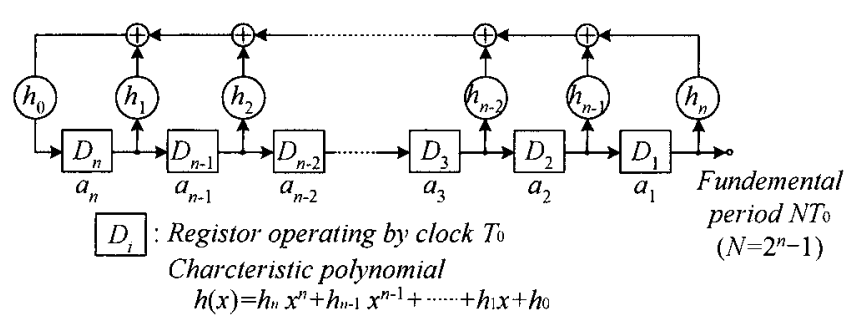

図 $2 \mathrm{M}$ 系列発生器の基本構成

Fig. 2. Fundamental configuration of maximum length sequence generator.

\section{表 1 特性多項式の一例}

Table 1. Example of characteristic polynomial.

\begin{tabular}{|c|c|c|c|}
\hline stage & length & feedback tap & polynomial \\
\hline 5 & 31 & {$[5,2]$} & $x^{5}+x^{2}+1$ \\
\hline \multirow{3}{*}{7} & \multirow{3}{*}{127} & {$[7,1]$} & $x^{7}+x+1$ \\
& & {$[7,3,2,1]$} & $x^{7}+x^{3}+x^{2}+x+1$ \\
& & {$[7,6,5,2,1]$} & $x^{7}+x^{6}+x^{5}+x^{2}+x+1$ \\
\hline \multirow{3}{*}{10} & \multirow{3}{*}{1023} & {$[10,3]$} & $x^{10}+x^{3}+1$ \\
& & {$[10,8,3,2]$} & $x^{10}+x^{8}+x^{3}+x^{2}+1$ \\
& & {$[10,5,2,1]$} & $x^{10}+x^{5}+x^{2}+x+1$ \\
\hline
\end{tabular}

は，一般にはシフトレジスタ各段の出力信号を適宜入力側 へ帰還することにより構成される。 $n$ 段シフトレジスタに よる最大長系列発生器の基本構成は图 2 に示す通りであり， 兴の出力系列 $\left\{a_{k}\right\}$ は次式で与えられる ${ }^{(3)}$ 。

$$
\left.\begin{array}{l}
a_{k}=\sum_{i=1}^{n} h_{i} a_{k-i}, \quad \bmod 2 \\
h_{i}=0 \text { or } 1, k=n+1, n+2, \ldots
\end{array}\right\} \ldots \ldots \ldots
$$

$\left(a_{1}, a_{2}, \ldots, a_{n}\right)$ は各レジスタの初期值で , すべてが零の 場合を除く任意の值に設定される。通常は最大長系列，す なわち基本周期が $N=2^{n}-1$ となるような帰還タップ係 数 $h_{i}$ が選定される。ここで, $a_{k-i}=x^{i} a_{k}$ となるような 単位遅延演算子 $x$ (図 2 中の各 $D_{i}$ に相当) を導入すると 式 (1) は次式

$$
\left.\begin{array}{l}
\sum_{i=0}^{n} h_{i} a_{k-i}=\left(\sum_{i=0}^{n} h_{i} x^{i}\right) a_{k}=0 \\
h_{0}=h_{n}=1
\end{array}\right\} \ldots \ldots \ldots
$$

のように変形される。多項式

$$
h(x)=\sum_{i=0}^{n} h_{i} x^{i} \quad, \quad h_{0}=h_{n}=1
$$

は特性多項式 (characteristic polynomial) と呼ばれ発生す る系列の性質を決定する重要な要因である。この $h(x)$ は $\mathrm{GF}(2)$ 上の多項式であり，演算はすべて $\mathrm{GF}(2)$ 上で行わ れる。また，この多項式は係数 $h_{i}$ が 1 である項の $x$ の次 数 $i$ のみを用いて $[n, n-1, \ldots, 1]$ のように略記される。た だ , 定数項は常に 1 であるため省かれ表記しないこととす る。 $n=5,7$ および 10 における特性多項式の一例を表 1 
に示す。

また，ある最大長系列発生器の特性多項式が $h(x)$ であ れば次の多項式

$$
h^{*}(x)=x^{n} h\left(x^{-1}\right) \cdot
$$

を有する最大長系列発生器が存在しうる。この多項式 $h^{*}(x)$ は, 多項式 $h(x)$ の相反多項式 (reciprocal polynomial) と 呼ばれている。なお表 1 にはこの相反多項式は含まれてい ない。

\section{4. 擬似ランダムエラービット 発生器の構成}

擬似ランダムエラービット発生器の具体的な構成法とし ては以下の 2 つの方法が考えられる。また，最大長系列発 生器のみによる擬似杂隹音発生と，本方式によるエラービッ 卜発生との異なる点について述べる。

〈 4 1 1 最大長系列発生器と 2 進カウンタ回路による構成 擬似ランダムエラービット発生器は 3 . で述べた最大長系列発 生器と 2 進カウンタ回路との組合せで構成され (4) (5) , 少の ブロック構成を図 3 に示す。最大長系列発生器の各レジスタ $D_{i}(i=1,2, \ldots, n)$ の内容は初期值 $\left(a_{1}, a_{2}, \ldots, a_{n}\right)$ から始 まり 10 進数で 1 から $N$ までの $N$ 個の值をほぼランダムに 変化し，炎の周期は $N T_{0}\left(T_{0}\right.$ :クロック周期 , $\left.N=2^{n}-1\right)$ で ある。一方 , カウンタ回路の各レジスタ $C_{i}(i=1,2, \ldots, n)$ は，10 進数で 1 から $N$ までを順番に推移するが，弚の周 期は, 最大長系列発生器の $N$ 倍の $N^{2} T_{0}$ である。すなわ ち, 最大長系列発生器の 1 周期の間一定値を維持すること となる。なお，カウンタ回路では全零は禁止とする。

このような条件のもとで, $D_{i}$ の内容と $C_{i}$ の内容が比較 器において比較され, 対応する $D_{i}$ と $C_{i}$ の内容がすべて同 一のときのみ , すなわち

$$
D_{i}=C_{i} \quad \text { All } i, i=1,2, \ldots, n \ldots \ldots \ldots \ldots
$$

が成り立つと比較器から 1 個のパルス (エラービット) が 生成・出力される。なお, ここで必要とする出力は比較器 から生成される出力パルスのみで, 最大長系列発生器から の出力は不要で, 例えば抵抗終端により消滅させられる。

本構成法においては, 最大長系列発生器の 1 周期間に唯 一つのパルス出力が得られ，兴の発生位置を 1 周期の始点 から $K_{j} T_{0}(j=1,2, \ldots, N)$ とすると $K_{j}$ はほぼランダム な整数となるものと推測される。

〈4 2〉 2 つの同一次数最大長系列発生器による構成 擬似ランダムエラービット発生器の別の構成法として，2 進カウンタの代わりに同一次数 $n$ の最大長系列発生器 を用いる方法が考えられ，弚のブロック構成を図 4 に示 す。この場合，両最大長系列発生器のレジスタ $D_{i}$ および $\bar{D}_{i}(i=1,2, \ldots, n)$ の内容がすべて同一 , すなわち

$$
D_{i}=\bar{D}_{i} \quad \text { All } i, i=1,2, \ldots, n \ldots \ldots \ldots \ldots
$$

のとき比較器から 1 個のパルスが出力される。 2 進カウン 夕を使用する構成と同樣, エラービット発生時期にランダ

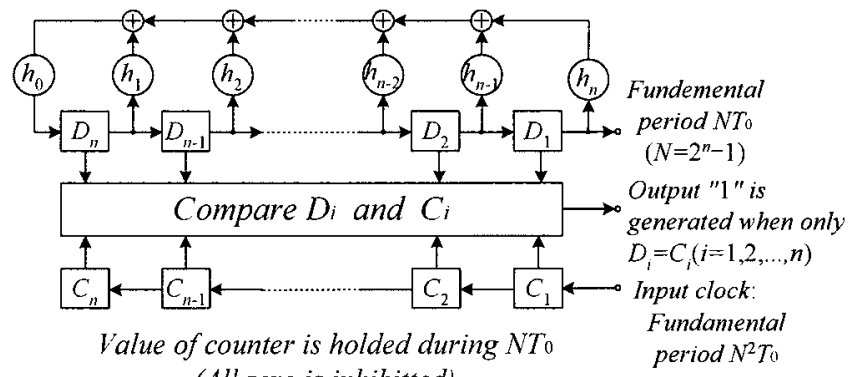
(All zero is inhibitted)

$D_{i}:(0,0, \ldots, 1) \cdots(1,1, \ldots, 1)$ almost randomly generated $C_{i}:(0,0, \ldots, 1) \cdots(1,1, \ldots, 1)$ sequencially generated

図 $3 \mathrm{M}$ 系列発生器と 2 進カウンタ回路による擬 似ランダムエラービット発生器のブロック構成

Fig. 3. Block configuration of pseudo-random error bit generator using maximum length sequence generator and binary counter.

Characteristic Polynomial $h(x)$

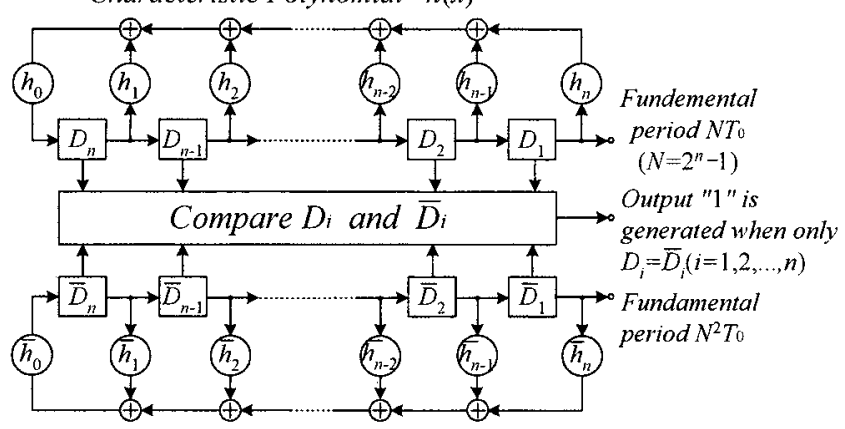

Characteristic Polynomial $\bar{h}(x)$

$D_{i}, \widetilde{D}_{i}:(0,0, \ldots, 1) \cdots(1,1, \ldots, 1)$ almost randomly generated

図 4 2つの同一次数の $\mathrm{M}$ 系列発生器による擬似 ランダムエラービット発生器のブロック構成

Fig. 4. Block configuration of pseudo-random error bit generator using two maximum length sequence generators.

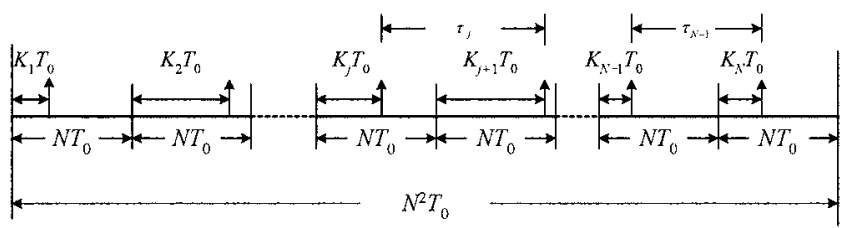

only one error bit is almost randomly generated a each fundamental period of $N T_{0}$, that means the $K_{j}(j=1,2, \ldots, N)$ are random integer.

図 5 ランダムエラービットの発生過程

Fig. 5. Generating process of random error bit.

ム性が期待できる。

いづれの場合も，カウンタ回路出力信号の 1 周期 $N^{2} T_{0}$ 内に $N$ 個のパルスが生成されることとなるため, 平均符号 誤り発生率，すなわちシミュレータとしての平均符号誤り 率 $P_{e}(\mathrm{BER}:$ bit error rate) は

$$
P_{e}=\frac{N}{N^{2}}=\frac{1}{N}=\frac{1}{2^{n}-1} .
$$

となる。エラービット発生の状況を図 5 に示す。また，段 
表 2 シフトレジスタの段数による平均符号誤り率

Table 2. Average bit error rate according to stage numbers of shift register.

\begin{tabular}{|c|l|}
\hline$n$ & Average bit error rate \\
\hline 10 & $9.775 \times 10^{-4} \fallingdotseq 10^{-3}$ \\
\hline 20 & $9.536 \times 10^{-7} \fallingdotseq 10^{-6}$ \\
\hline 30 & $9.313 \times 10^{-10} \fallingdotseq 10^{-9}$ \\
\hline 40 & $9.094 \times 10^{-13} \fallingdotseq 10^{-12}$ \\
\hline
\end{tabular}

数 $n$ に対する平均符号誤り率を表 2 に示す。提案するラン ダムエラービット発生器は, 2 進回路を基本としているた め得られる平均符号誤り率も 2 のべき乗となり 10 のべき 乗ではないが, 段数 $n$ に応じて平均符号誤り率を制御しう る点に特徵がある。

〈4. 3〉 最大長系列発生器による擬似雑音発生と本方式 によるエラービット 発生の違い ここで, 単一の最大長 系列発生器による擬似杂倠音発生と, 提案方式によるエラー ビット発生の違いについて述べる。図 2 に示すとおり最大 長系列発生器はシフトレジスタの段数および帰還タップの 数により擬似的な不規則信号が出力されることとなる。こ の信号は $N=2^{n}-1$ の周期により，“0”が出力される信 号の数は $\left(2^{n-1}\right)-1$ 個となる性質を有し $\mathrm{PN}$ 信号を生成 する用途に用いられる。結果として平均符号誤り率は $1 / 2$ となり最大長系列発生器回路を用い伝送路の信号をシミュ レートすることは困難である。

そこで提案方式では 1 周期において 1 個の誤り発生ビッ 卜を有する回路を構成した。これは $\langle 4 \cdot 1\rangle\langle 4 \cdot 2\rangle$ で述べた とおり, カウンタ回路と比較器を用いることにより最大長 系列発生器の各シフトレジスタの内容とカウンタ回路の各 シフトレジスタの内容とを比較器により比較し両者の值が 一致する場合に出力信号 (エラービット) が得られること を示した。このシミュレータ回路を用いると受信情報信号 としては誤り発生時点で反転ビットを出力するディジタル 信号が得られるが，この信号を利用しフェージング発生も しくは杂隹音発生などに変換する回路へ応用することにより 種々の用途への利用が可能と考えられる。

\section{5. エラービット 発生間隔の解析}

〈 5 1 1 隣接エラービット 間隔の確率分布特性 カウ ンタの 1 周期に相当する時間 $N^{2} T_{0}$ 内で $N$ 個のエラービッ 卜が発生されるが, これは最大長系列発生器の 1 周期内に 1 個 (bit) という制約がある。このため, エラービット発生 間隔にもある種の分布 (制限) が生じることが予測される。 したがって以下ではエラービット発生間隔の分布状況につ いて検討する。

クロック周期 $T_{0}$ で基準化した隣接エラービット間隔 $\tau_{j}$ は, 図 5 を参照すると次のように求められる。

$$
\tau_{j}=N-K_{j}+K_{j+1} \quad, \quad j=1,2, \ldots, N-1
$$

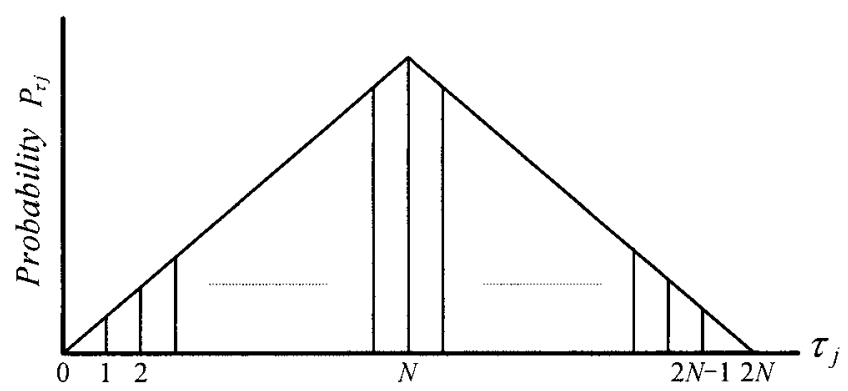

図 6 エラービット発生間隔の分布

Fig. 6. Distribution of adjacent error bit interval.

表 3 実例と推定の標準偏差 (1)

Table 3. Difference between actual case and estimation (1).

\begin{tabular}{|c|c|c|c|c|c|}
\hline \multirow{2}{*}{$n$} & \multicolumn{3}{|c|}{ Actual } & \multicolumn{2}{c|}{ Estimation } \\
\cline { 2 - 5 } & $h(x)$ & $\bar{\tau}$ & $\sigma_{s}$ & $\bar{\tau}$ & $\sigma_{\bar{t}}$ \\
\hline \multirow{2}{*}{5} & {$[5,2]$} & 31 & 14.521 & \multirow{2}{*}{31} & \multirow{2}{*}{12.649} \\
\cline { 2 - 5 } & {$[5,4,2,1]$} & 31 & 12.996 & & \\
\hline \multirow{2}{*}{10} & {$[10,7,6,5,4,3,2,1]$} & 1023 & 415.821 & \multirow{2}{*}{1023} & \multirow{2}{*}{417.638} \\
\cline { 2 - 4 } & {$[10,8,3,2]$} & 1023 & 418.034 & & \\
\hline \multirow{2}{*}{16} & {$[16,12,3,1]$} & 65535 & 26814.689 & \multirow{2}{*}{65535} & \multirow{2}{*}{26754.552} \\
\cline { 2 - 4 } & {$[16,15,4,2]$} & 65535 & 26662.657 & & \\
\hline
\end{tabular}

ここで $\tau_{j}$ の最大值は $K_{j}=1, K_{j+1}=N$, 最小值は $K_{j}=N$ ， $K_{j+1}=1$ のとき生じるため以下の式が成立する。

$$
1 \leq \tau_{j} \leq 2 N-1, \quad j=1,2, \ldots, N-1 \cdots \cdots
$$

最大長系列発生器のレジスタ内容 (值) は 1 から $N$ ま での值をほぼランダムに推移するため $K_{j}$ の值もほぼラン 公で, 光の確率密度分布は一樣分布と考えられる。いま， $K_{j}$ の確率密度分布を $P_{k j}$ と表すと, 弚の平均值 $\bar{K}$ および 分散 $\sigma_{k}^{2}$ は

$$
\left.\begin{array}{c}
\bar{K}=\sum_{j=1}^{N} P_{k j} K_{j}=\frac{1}{N} \sum_{j=1}^{N} K_{j}=\frac{1}{2}(N+1) \\
\sigma_{k}{ }^{2}=\sum_{j=1}^{N} P_{k j}\left(K_{j}-\bar{K}\right)^{2}=\frac{1}{12}\left(N^{2}-1\right)
\end{array}\right\} .
$$

となる。次に $\tau_{j}$ の確率密度分布は式 $(8)$ から分かるように $K_{j}$ と $K_{j+1}$ の差分分布であり, 光の確率密度分布 $P_{\tau_{j}}$ は 図 6 を参照すると次式で表される。

$$
P_{\tau_{j}}=\left\{\begin{array}{lr}
\frac{1}{N^{2}} \tau_{j} & 1 \leqq \tau_{j} \leqq N \\
\frac{1}{N^{2}}\left(2 N-\tau_{j}\right) & N \leqq \tau_{j} \leqq 2 N-1
\end{array}\right.
$$

これを用いると $\tau_{j}$ の平均値 $\overline{\tau_{j}}$ と分散 $\sigma_{\tau}^{2}$ は次のように求 められる。 


$$
\begin{aligned}
\bar{\tau} & =\sum_{j=1}^{2 N-1} P_{\tau j} \tau_{j}=\sum_{j=1}^{N} \frac{\tau_{j}^{2}}{N^{2}}+\sum_{j=N+1}^{2 N-1} \frac{\tau_{j}}{N^{2}}\left(2 N-\tau_{j}\right)=N \\
\sigma_{\tau}{ }^{2} & =\sum_{j=1}^{2 N-1} P_{\tau j}\left(\tau_{j}-\bar{\tau}\right)^{2} \\
& =\sum_{j=1}^{N} \frac{\tau_{j}}{N^{2}}\left(\tau_{j}-\bar{\tau}\right)^{2}+\sum_{j=N+1}^{2 N-1} \frac{1}{N^{2}}\left(2 N-\tau_{j}\right)\left(\tau_{j}-\bar{\tau}\right)^{2} \\
& =\frac{1}{6}\left(N^{2}-1\right)
\end{aligned}
$$

この分布は, $K_{j+1}-K_{j}$ のすべての組合せ $\left(N^{2}\right.$ 個) を含 むものであるが , 本方法で使用するものはこのうちの $N$ 個 のみで，また $K_{j+1}$ と $K_{j}$ は完全に独立でないことを考慮 すると正確な分布を示しているとは言えない。しかし， $N$ が大きくなれば近似的には式 (12) で示される理想的な三 角分布に収敛するものと期待される。

本方法における実際の分布と理想的三角分布との近似度 を示す尺度としてここでは標準偏差の一致度あるいは不一 致度を用いる。両者の標準偏差の不一致度 (偏差) は, 特 性多項式にも依存するが, 光の最悪值は次数 $n$ が大となる に伴い減少し， $n$ が 10 以上では, ほぼ $1 \%$ 以下に収束する。 したがって， $n>10$, 偏差 1\%以下を一つの基準と考える

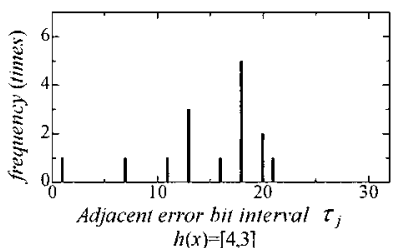

$h(x)=[4,3]$

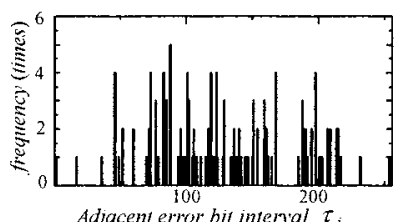

Adjacent emor bit interval $\tau$ $h(x)=[7,6,3,1]$

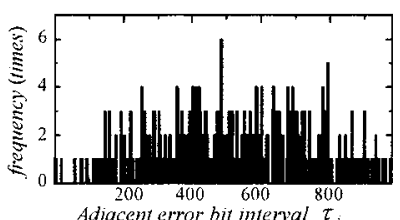

$h(x)=[9,7,5,4,3,2]$

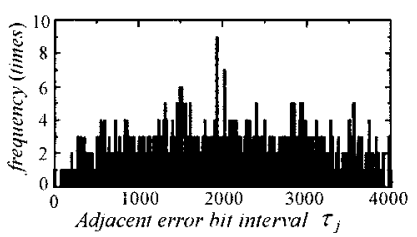

$h(x)=[11,9,8,7,4,1]$

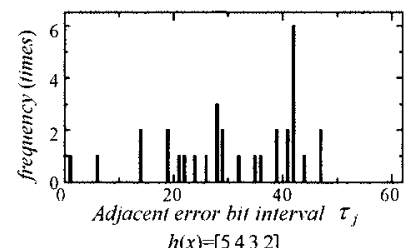

$h(x)=[5,4,3,2]$

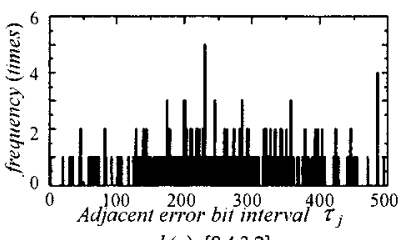

$h(x)=[8,4,3,2]$

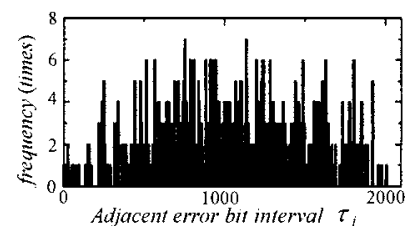

$h(x)=[10,9,4,2]$

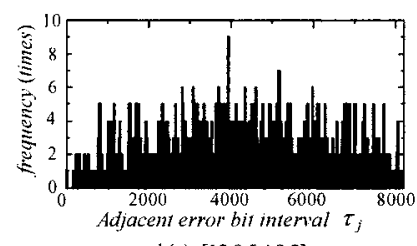

$h(x)=[12,9,5,4,3,2]$
図 7 特性多項式の次数増加による三角分布発生 の推移

Fig. 7. Transition of triangular distribution by the increase of a degree of characteristic polynomial.
のが妥当である。ただし，この規準は理論的根拠ではなく， 図 7 に示すように幾つかの計算機シミュレーション結果か ら推論したものである。図より概ね $n=8$ 辺りから近似的 に三角分布の傾向か顕著に現れていることが見受けられる。

上記の検討結果は， 2 種の構成法に対する一般論であり 詳細においては光れ卆れの構成法により特性にやや差異が 見受けられる。以下には, 各構成法による具体的数值例を あげ上記推定值との相違および両構成法における差異につ いて説明する。

表 4 エラービット発生過程と隣接エラービット 間隔の分布 (1)

Table 4. Generating process error and adjacent error bit interval (1).
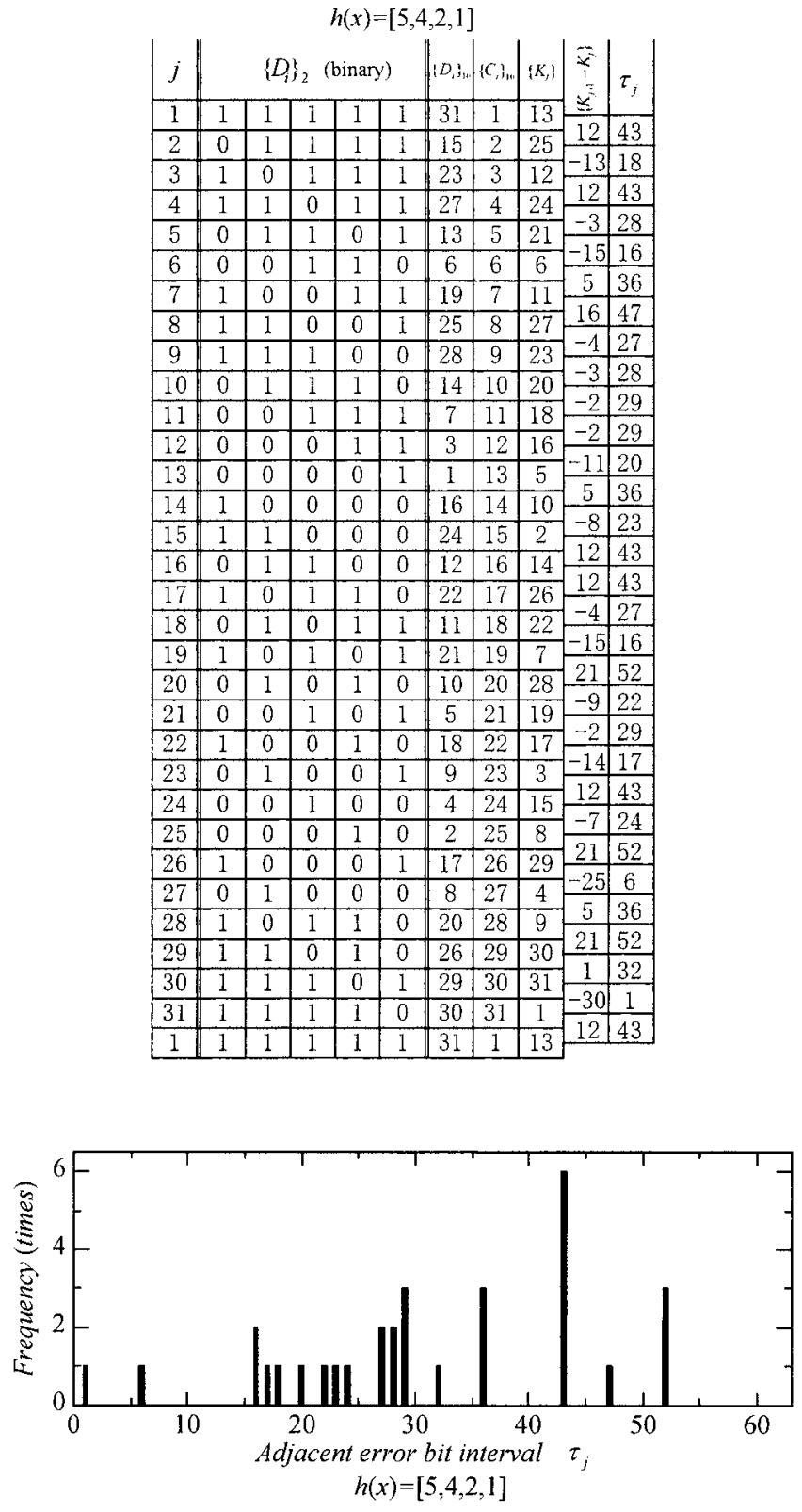

図 85 次多項式のエラービット発生の分布

Fig. 8. Distribution of adjacent error bit interval of five degree polynomial. 
次に本構成法による具体的数值例をあげ上記の推測が妥 当であることを明らかにする。

〈 5. 2〉 最大長系列発生器と 2 進カウンタ回路による構 成 5 次多項式による最大長系列発生器と 2 進カウンタ 回路で構成した際の各レジスタ内容の推移とエラービット 発生間隔を求めた結果を表 4 に, 隣接エラービット間隔の 分布を図 8 に示す。また, 式 (12) から算出される平均值, 標準偏差と実際の特性との比較を 5 次，10 次および 16 次 多項式の場合につき表 3 に示す。

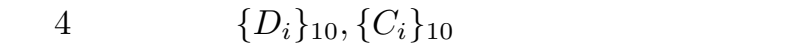
生器およびカウンタ回路のレジスタ内容の 10 進表示であ り，両者が一致するとき発生するエラービットの最大長系 列の 1 周期内における位置を $K_{j}$ と表す (式 (5) 参照)。

ここでは, 表 3 の Estimation の場合には $K_{j}$ の出現に 完全なランダム性を仮定しているため特性多項式による差 異は現れていないが，実際には特性多項式によりランダム 性が異なり，したがって隣接エラービット間隔の分布特性 も若干相違することとなる。关の相違が標準偏差のばらつ きに現れている。また，特性多項式による相違および符号 誤り率が小さい場合を表す例として 16 次多項式の場合の 計算機シミュレーションによる結果を図 9 に示す。このと きの平均符号誤り率は約 $1.53 \times 10^{-5}$ となる。

〈5. 3〉 2 つの同一次数最大長系列発生器による構成 5 次多項式を用いた 2 つの最大長系列発生器で構成した場 合の両発生器内の各レジスタ内容の推移とエラービット発

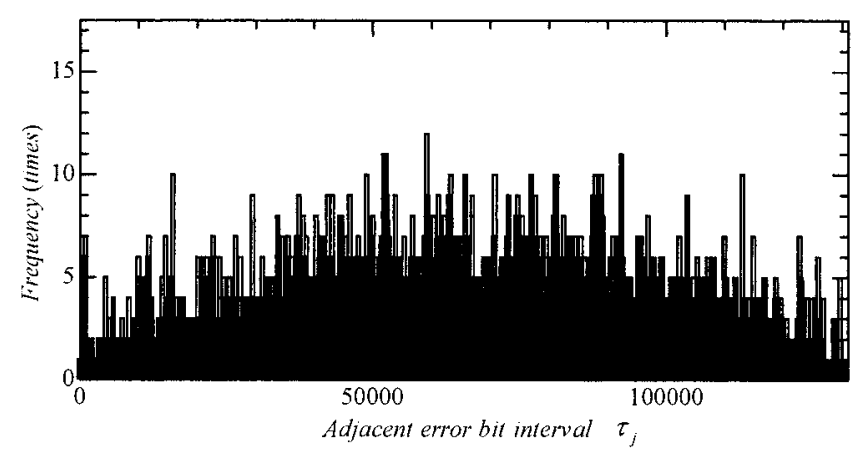

(a) $h(x)=[16,12,3,1]$

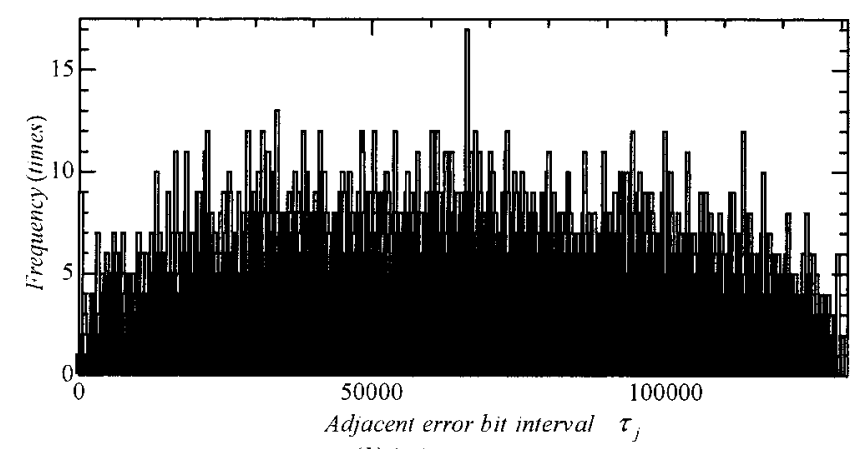

(b) $h(x)=[16,15,4,2]$

図 916 次多項式のエラービット発生の分布

Fig. 9. Distribution of adjacent error bit interval of sixtenn degree polynomial.
生間隔を表 5 に, 隣接エラービット間隔の分布特性を図 10 に, またと平均値と標準偏差の例を表 6 に示す。隣接工 ラービット間隔の分布は， $\langle 5 \cdot 2\rangle$ の場合とは樣相が異なり $\tau_{j}=2^{5}$,一般には $\tau_{j}=2^{n}$ の頻度が最も高く，これを中心 として他はほぼ一樣に分布している。特に， $h(x)$ と $\bar{h}(x)$ が同一多項式の場合には

$$
K_{j+1}-K_{j}=1 \quad, \quad j=1,2, \ldots, N-1 \cdots
$$

が成り立つため

$$
\tau_{j}=N+1=2^{n} \quad, \quad j=1,2, \ldots, N-1 \cdots
$$

となり, 図 $10(a)$ に示すようにすべての隣接エラービット 間隔は等しく，ランダム性は消滅することとなる。この関 係は 2 つの多項式 $h(x), \bar{h}(x)$ による最大長系列発生器の類 似性に起因しており, 両出力系列の相互相関関数によりあ る程度のランダム性を推測することができる。レジスタ $D_{i}$ と $\bar{D}_{i}$ の内容が一致したときにエラービットが出力される が, 弚の時間間隔が不規則であればよりランダム性が強く なる。この関係は $D_{i}$ と $\bar{D}_{i}$ の内容の相関性により決まるが， レジスタの内容は順次出力端子より送出されるため, 最大 長系列の相関性と置き換えて評価することができる。特性 多項式 $h(x), \bar{h}(x)$ を有する 2 つの最大長系列 $\left\{u_{i}\right\},\left\{v_{i}\right\}$

表 5 エラービット発生過程と隣接エラービット
間隔の分布 $(2)$

Table 5. Generating process error and adjacent error bit interval (2).

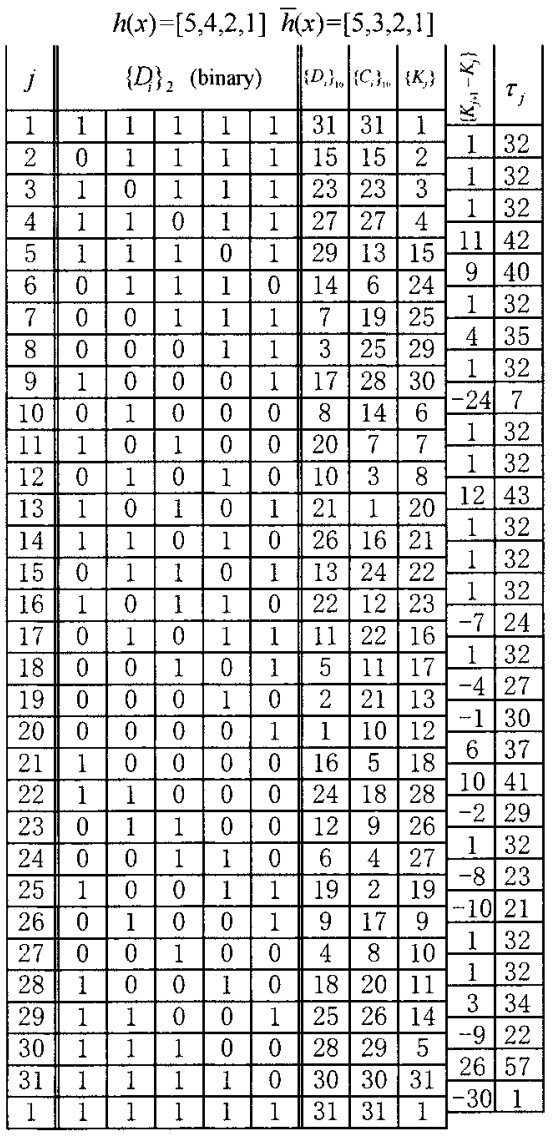




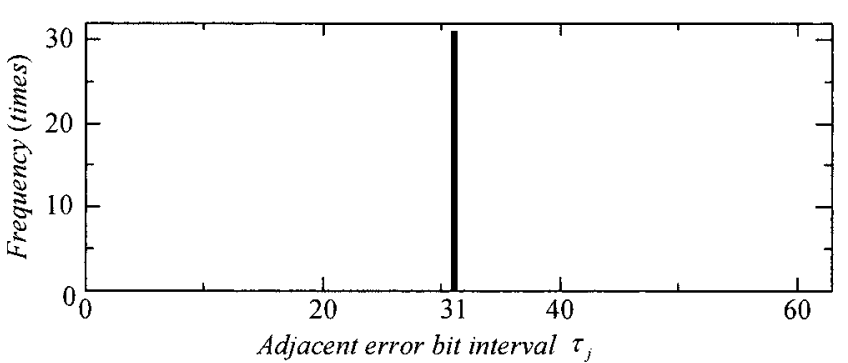

(a) $h(x)=\bar{h}(x)=[5,4,2,1]$

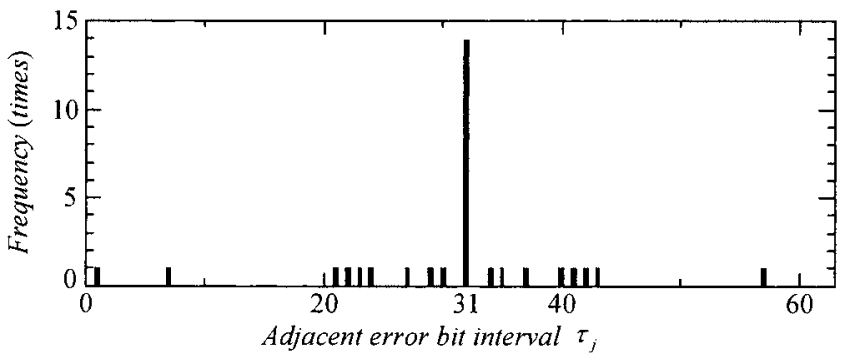

(b) $h(x)=[5,4,2,1], \bar{h}(x)=[5,3,2,1]$

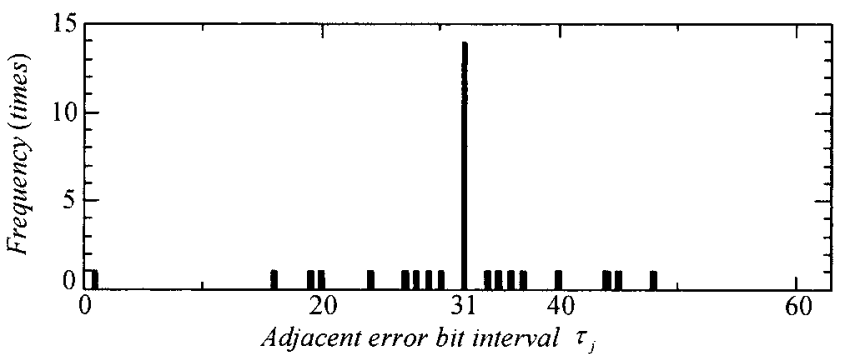

(c) $h(x)=[5,4,2,1], \bar{h}(x)=[5,2]$

图 102 つの $\mathrm{M}$ 系列発生器による構成のエラー ビット発生分布

Fig. 10. Distribution of adjacent error bit interval of two Maximum length sequence.

表 6 実例と推定の標準偏差 $(2)$

Table 6. Difference between actual case and estimation (2).

\begin{tabular}{|c|c|c|c|c|c|c|}
\hline \multirow{2}{*}{$n$} & \multicolumn{4}{|c|}{ Actual case } & \multicolumn{2}{|c|}{ Estimation } \\
\hline & $h(x)$ & $\bar{h}(x)$ & $\bar{\tau}$ & $\sigma_{\tau}$ & $\bar{\tau}$ & $\sigma_{\tau}$ \\
\hline \multirow{3}{*}{4} & & {$[4,3]$} & \multirow{3}{*}{15} & 5.404 & \multirow{3}{*}{15} & \multirow{3}{*}{6.110} \\
\hline & {$[1,1]$} & {$[4,1]$} & & 0 & & \\
\hline & {$[4,3]$} & {$[4,1]$} & & 5.404 & & \\
\hline \multirow{6}{*}{5} & \multirow{3}{*}[5,4,2,1]{} & {$[5,3,2,1]$} & \multirow{3}{*}{31} & 11.751 & \multirow{6}{*}{31} & \multirow{6}{*}{12.649} \\
\hline & & {$[5,2]$} & & 8.621 & & \\
\hline & & {$[5,4,2,1]$} & & 0 & & \\
\hline & \multirow{3}{*}[5,2]{} & {$[5,4,3,2]$} & \multirow{3}{*}{31} & 9.046 & & \\
\hline & & {$[5,3]$} & & 11.303 & & \\
\hline & & {$[5,2]$} & & 0 & & \\
\hline
\end{tabular}

に対する相互相関関数 $C_{u v}(p)$ は次式で定義される ${ }^{(6)}$ 。

$$
C_{u v}(p)=\frac{1}{N} \sum_{i=0}^{N-1} u_{i} v_{i+p}
$$

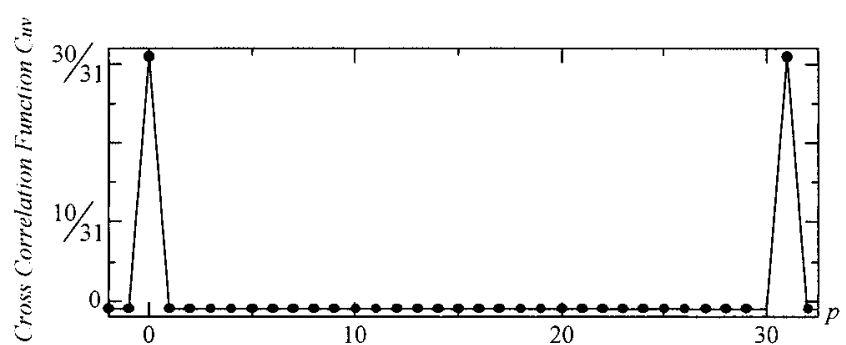

(a) $h(x)=\bar{h}(x)=[5,4,2,1]$
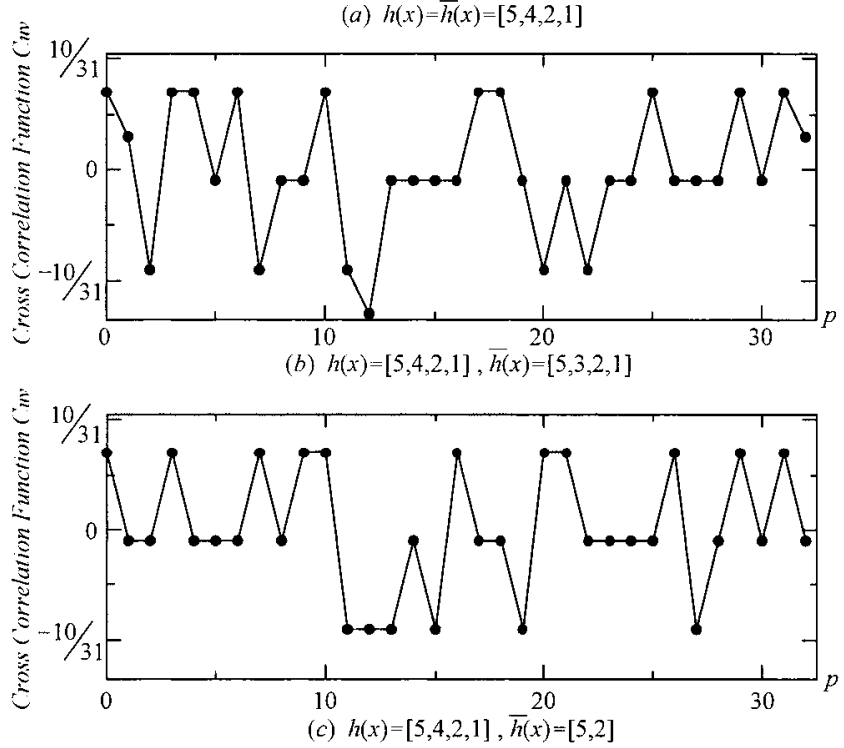

図 112 つの M 系列発生器による相互 (自己) 相関関数

Fig. 11. Cross (Auto) correlation function between two maximum length seqence.

ここで, $\left\{u_{i}\right\},\left\{v_{i}\right\}$ の論理值 $(1,0)$ は $(+1,-1)$ に変換 して算出するものとする。また $\left\{u_{i}\right\}=\left\{v_{i}\right\}$ ，すなわち $h(x)=\bar{h}(x)$ の場合には自己相関関数となる。上式を用い て图 10 で用いた各 $h(x)$ に対する相関関数を求めた結果を 图 11 に示す。図より, (a) は $h(x)$ と $\bar{h}(x)$ が同一多項式の ため相関か強く，したがってランダム性が失われるが , (b) , (c) は相関性にややばらつきがあるがランダム性の点から は, ほぼ同等と見ることができる。すなわち，特性多項式 $h(x)$ と $\bar{h}(x)$ が同次で異なっていれば若干の相違は現れる もののほぼ同等のランダム性を確保しうることとなる。

〈 5 4 42 つの異なる回路構成の比較検討 2 種の構成 法を比較すると一概に弚の優劣を決めることはできないが， 類似の最大長系列発生器を使用するよりは, 2 進カウンタ 回路で構成したほうがランダム性の点でやや優れていると 思われる。このことは表 3 および表 6 の標準偏差の值を比 較すると理解できる。

最大長系列発生器と 2 進カウンタ回路で構成する方法で は, レジスタ $D_{i}$ の変化はランダムであるのに対し, カウ ンタレジスタ $C_{i}$ の変化は 1 ずつ増加する規則性を有して いる。一方，2つの最大長系列発生器による構成では, 双 方のレジスタ $D_{i}, \bar{D}_{i}$ がともにランダムに推移するため動 作が複雑であるが， 5 次多項式までのシミュレーション結 


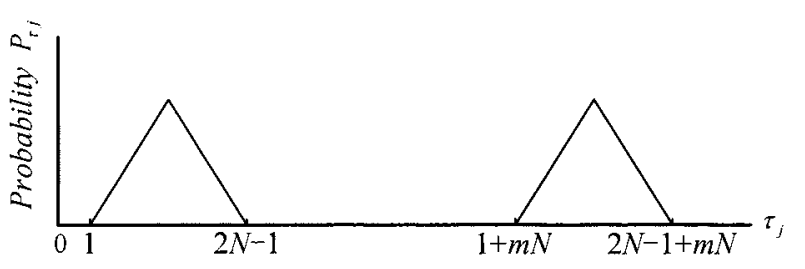

(a) Distribution of adjacent error bit interval

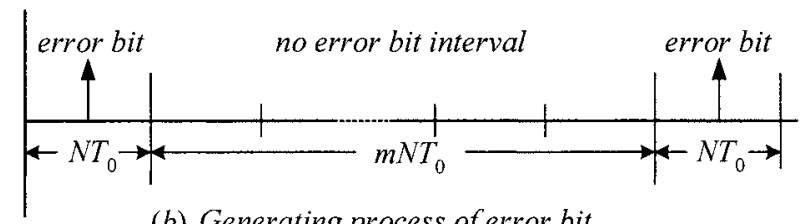

(b) Generating process of error bit

図 12 一樣分布実現の概念

Fig. 12. Distribution of adjacent error bit interval.

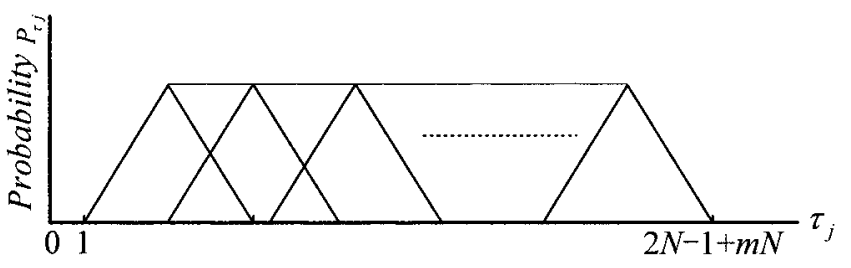

図 13 三角分布の重畳による一樣分布の実現

Fig. 13. Realization of uniform distribution by superpose of triangular distribution.

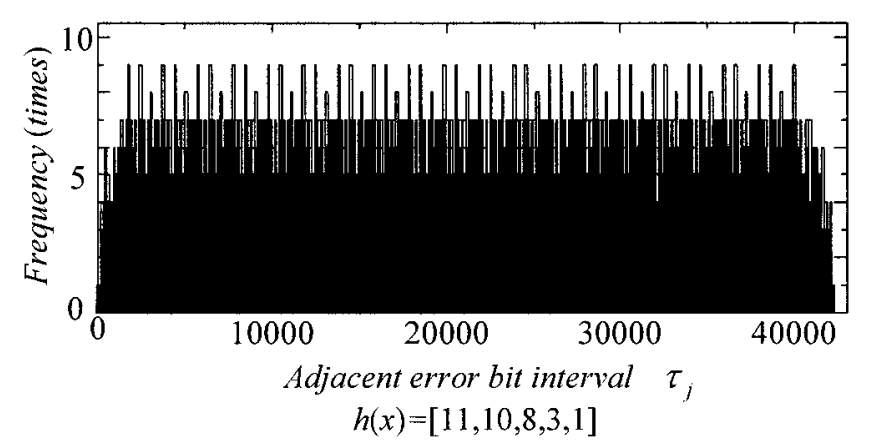

図 14 一樣分布実現のシミュレーション結果

Fig. 14. Simulation result of uniform distribution.

果では上記のような推論が導かれる。

〈 5. 5〉 エラービット間隔の一様分布近似実現法 こ れまでに述べたシミュレータの隣接エラービット間隔はほ ぼ三角分布を示すことを明らかにしてきたが，これを基本 として近似的に一樣分布を実現する方法について述べる。

擬似ランダムエラービット発生器の 1 周期 $N$ ビット中 に 1 つのエラービットを発生させた後 $m$ 周期 $\left(m N T_{0}\right)$ に わたりエラービットの発生を休止させるとエラービット 間隔 $\tau_{j}$ の分布は $m N T_{0}$ だけシフトし $(1+m N) T_{0}$ から $(2 N-1+m N) T_{0}$ の間に分布する。この関係を図 12 に示す。 このシフトされた三角分布を $M$ 個 $(m=0,1,2, \ldots, M-1)$
重畳させると図 13 のモデル図のように近似的に一樣分布 を実現することができる。このように $M$ 個の三角分布を シフトし重畳させた分布におけるエラービット系列の 1 周 期 $T_{U}$ は次式となる。

$$
T_{U}=\sum_{m=0}^{M-1}(m+1) N^{2} T_{0}=\frac{1}{2} M(M+1) N^{2} T_{0}
$$

また，この間に発生するエラービットは $M N$ であること より平均符号誤り率 $P_{e}$ は

$$
P_{e}=\frac{M N}{\frac{1}{2} M(M+1) N^{2}}=\frac{2}{(M+1)\left(2^{n}-1\right)}
$$

で与えられる。なお，この方法では，1つの三角分布があ る一定の時間内に集中しており，1 周期内に分散していな いため真の意味でのランダム性とは言えないが，長時間内 にわたる観測としては, 近似的にはランダムな一樣分布と 見ることができる。本方法によるシミュレーション結果を 図 14 に示す。この結果から上記推論が立証されているこ とが明らかである。

\section{6. 擬似バーストェラービット 発生器の構成}

4. で述べたランダムエラービット発生器は, 最大長系列 の周期 $N$ の間にエラービット 1 個を発生させる構成となる。 このエラービットに続いてパルスを連続して発生させ , 光 の長さにランダム性を付与すれば近似的にバーストエラー ビット発生器を実現しうることとなる。ここでは, 前記ラ ンダムエラービット発生器を適用することにより擬似バー ストエラービット発生器を構成する方法について述べる。

〈 $6 \begin{array}{ll}6 & 1\rangle\end{array}$ 基本構成擬似バーストエラービット発生器 は, 次数の異なる 2 つのランダムエラービット発生器, バー ストエラービットの開始，終了を制御するスイッチおよび 実際にバーストエラービットを送出するパルス生成器より 構成される。具体的ブロック構成を图 15 に示す。高い次 数の生成多項式で構成されるランダムエラービット発生器 (CircuitA) の出力がランダムエラーの開始を決定し, 次数 の低いランダムエラービット発生器 (CircuitB) がランダ ムエラーの終了時点を制御する。乥の動作概要は以下に示 す通りである。

擬似ランダムエラービットを発生する CircuitAの出力は, スイッチを ON にしパルス発生器からの連続パルスを送出 するとともに，同時にCircuitBを起動し，CircuitBから 発生されるランダムパルスによりスイッチを OFF とし , パ ルス発生器からの出力を停止させる。このときのCircuitB の動作は Circuit $A$ と同樣でレジスタ $C_{B i}$ と $D_{B i}$ の内容 が比較されすべての $C_{B i}$ と $D_{B i}$ の内容が一致, すなわち

$$
D_{B i}=C_{B i} \quad \text { All } i=1,2, .
$$

が成り立つとパルス 1 個が生成される。CircuitB は周期 


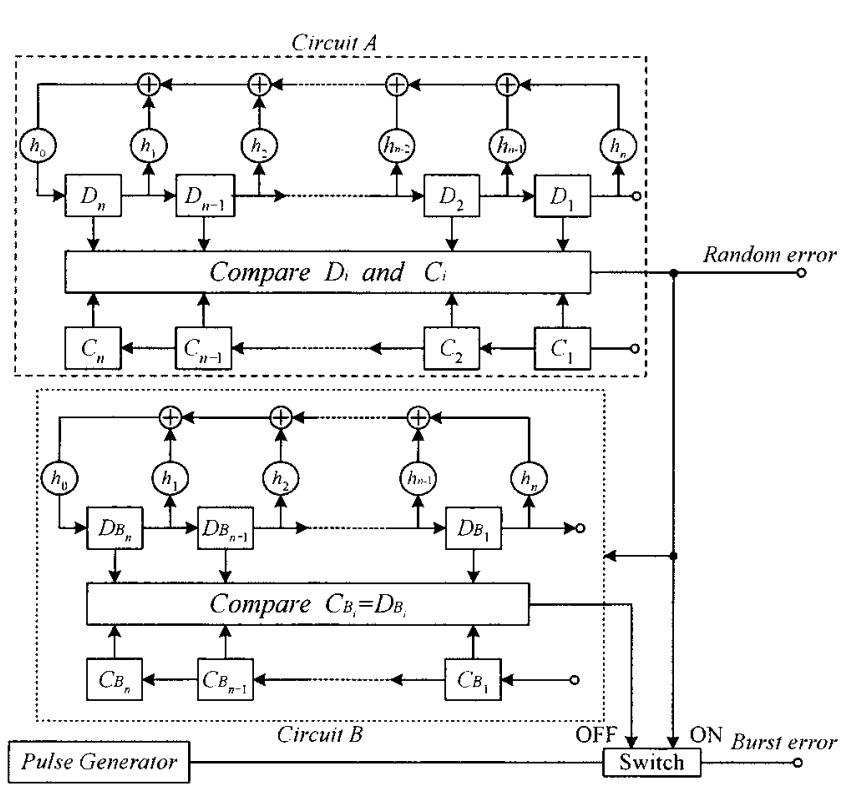

図 15 擬似バーストエラービット発生器の基本 構成

Fig. 15. Basic configuration of pseudo-burst error generator.

が Circuit A より短いため 1 周期動作後は初期状態に戻り 停止し，次にCircuitA からの出力を受けるまで待機して いることとなる。

なお，CircuitBの起動·停止は別途準備するクロック回 路の起動·停止と連動して行われる。すなわち, Circuit A からの出力によりクロック回路が動作を開始し, 最初のク ロックでCircuitB が起動し，また停止は $C_{B_{i}}$ または $D_{B_{i}}$ の最終值を検出することにより 1 周期終了を自動的に検知 しクロックを停止することにより実行される。

以上により，最大バースト長が CircuitB の周期と等し いバーストエラービットが発生される。2つのランダムエ ラービット発生器 $A, B$ ともに关の出力はランダム性を有 していることにより, バーストの開始位置, バースト長と もにランダム性が期待できる。

〈6.2〉 バーストエラービット 発生確率の解析 2 つの ランダムエラービット発生器 Circuit $A$ および $B$ の生成

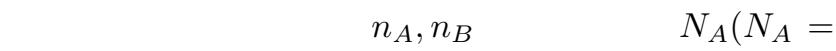
$\left.2^{n_{A}}-1\right), N_{B}\left(N_{B}=2^{n_{B}}-1\right),\left(N_{A}>N_{B}\right)$ とする。両回 路からの出力パルスの制御によりスイッチを通して送出さ れるランダムエラービットの総数は, CircuitB の 1 周期 $\left(N_{B}{ }^{2} T_{0}\right)$ 当りでは次のように求められる。

$$
E_{B}=\sum_{j=1}^{N_{B}} K_{j}=\frac{1}{2} N_{B}\left(N_{B}+1\right) .
$$

ここで, $K_{j}$ は 1 周期の始点からの基準化時間間隔で 1 から $N_{B}$ までの整数を一順する。

上記のエラービット総数を Circuit Aの 1 周期 $\left(N_{A}{ }^{2} T_{0}\right)$ に換算すると，Circuit $A$ は 1 周期内に $N_{A}$ 個のパルスを 出力し, またCircuitB は $N_{B}$ 個の始点からの時間の異な

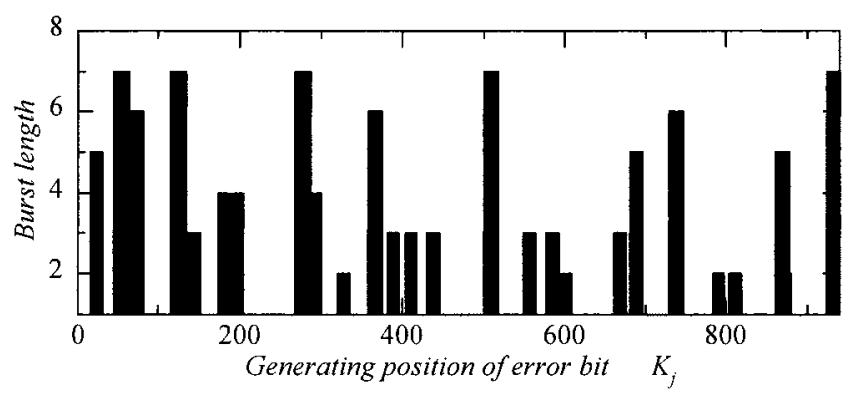

図 16 全周期 $N_{A}^{2} T_{0}$ における擬似バーストエ ラービットの発生分布

Fig. 16. The occurrence distribution of the pseudo burst error bit in period $N_{A}{ }^{2} T_{0}$.

るパルスを生成するため, 弚の総数 $E_{A}$ は

$$
E_{A}=E_{B} \frac{N_{A}}{N_{B}}=\frac{1}{2} N_{A}\left(N_{B}+1\right) .
$$

となる。この 1 周期間の総情報パルス送出数は $N_{A}{ }^{2}$ であ ることより平均バースト符号誤り率 $P_{\text {Burst }}$ は

$$
P_{\text {Burst }}=\frac{E_{A}}{N_{A}^{2}}=\frac{N_{B}+1}{2 N_{A}}
$$

となる。なお，ここでは $N_{A} / N_{B}$ が整数であると仮定して いるが, 整数とならない場合は誤差を伴うこととなる。し かし, 通常は $N_{A} \gg N_{B}$ と設定することが多くあまり問題 にならないものと思われる。なお , バースト長は, エラー ビット数 1 から $N_{B}$ に対して一樣分布を呈する。

1 例として, CircuitA $A$ 次多項式のランダムエラー ビット発生器，CircuitB 3 次多項式で構成した場合の 全周期 $N_{A}{ }^{2} T_{0}$ におけるバーストエラービット発生分布を 算出した結果を图 16 に示す。图で横軸はエラービット発 生位置を示し, 各エラービットの幅および緃軸の值がバー スト長を示す。エラービット発生位置およびバースト長と もにランダム性を有することが伺われ，上記推論が立証さ れる。

ここでのバーストエラービットはソリッドバースト誤り に分類されるが (7), 異なる次数となるCircuitB の出力を 重畳することにより一般的なバースト誤りの出力も可能と なる。

本節では, 擬似ランダムエラービット発生器を利用する ことにより, バーストェラービットの発生が可能であるこ とを示した。これは無線通信におけるフェージング, ある いは同期はずれによるバースト誤り発生状況を想定したも のである。

本論文では, バースト長の制御を別途準備したバースト エラー発生器 $($ CircuitB) で行う方法を採用しているため バースト長は一樣分布になると思われるが, 別の方法とし てノイズ系モデルでよく用いられる隠れマルコフ過程を仮 定した場合には弚の分布はポアソン分布になることが予想 される。なお，乥の実現手段および両者の優劣については 今後の課題とする。 


\section{7. むすび}

一定の平均符号誤り率を実現する伝送路シミュレータの 一設計法について述べるとともにこれらの特性評価を示し た。最大長系列発生器とカウンタ回路および 2 つの最大長 系列発生器による構成法を提示したが, 簡易なハードウェ アで構成しうる点に特徵がある。

本論文における成果は以下のように要約される。

（1）最大長系列発生器のランダム性を利用し，カウン タ回路および比較器を用い擬似的にランダムエラー ビットを発生する方法を提案し，炎の回路構成を提 示した。この出力は 1 周期 $N$ に 1 個のパルスをラ ンダムに出力する特性をもつ。

(2) 計算機シミュレーションによりとのランダム特性 を立証することを試み，理論による推定と実際に構 成する回路との比較を行い, 類似点, 相違点を明ら かにした。

（3）本方法において，エラービット発生間隔の分布は 次数が高く, データ量が多くなるに伴い予測した三 角分布に近くなることが明らかとなった。これは最 大長系列発生器における各シフトレジスタの内容の ランダム性に起因するものと考えられる。

(4) 隣接エラービット発生間隔の分布を示す三角分布 をシフトすることにより近似的に一樣分布を実現す る方法を試み，計算機シミュレーションにより光の 特性を示した。これによりエラービット発生間隔の 偏りを軽減しうることを明らかにした。

（5） 2 つの擬似ランダムエラービット発生器の組合せ により， 1 周期中にバースト性のエラービットを発 生させる回路を提案し数値例とともに午の妥当性を 示した。

今後の課題は実際に回路として実現し，㒷の特性を証明 することにある。次数の高い回路構成によりシミュレーショ ンおよび解析を行い，実用的なレベルで本方式を実現する ことである。また，隠れマルコフモデルおよびギルバート モデルによるバースト誤り発生過程との関連性についての
検討も重要な課題である。

(平成 16 年 3 月 3 日受付, 平成 16 年 9 月 28 日再受付)

文献

(1) BERNARD KSKLAR : Digital Communications , PrenticeHall International,Inc. (2001)

( 2 ) ITU-T Recommendation O.150 : "General Requirements for Instrumentation for Performance Measurements on Digital Transmission Equipment" (1996-5)

（3）柏木 潤：M 系列と炎の応用，昭晃堂 (1996)

(4) K. Tanaka et al : "Design of the Transmission Line Simulator having a Certain Bit Error Rate", Proc. 2000 Asia-Pacific Symposium on Broadcasting and Communications. No.GLE10, pp.292-297, Bangkok, Thailand (2000-12)

(5) N. Tsuchiya and K. Tanaka: "Design of the Transmission Line Simulator having a Certain Bit Error Rate", Proceedings of the School of Engineering Tokai University, Vol.41, No.1, pp.19-24 (2001-1)(in Japanese) 土屋如右・田中公男 : 「一定の符号誤り率を有する伝送路シミュレー 夕の設計」, 東海大学紀要工学部，41, 1, pp.19-24 (2001-1)

（6）宮川 洋・岩垂好裕·今井秀樹：符号理論，昭晃堂 (1973)

( 7 ) Gilbert E.N. : "Capacity of a burst-noise channel" , Bell Syst. Tech. J., pp.1253-1265 (1960)

土 屋 如 右 (学生員) 1977 年 11 月 24 日生。 2000 年 3 月東

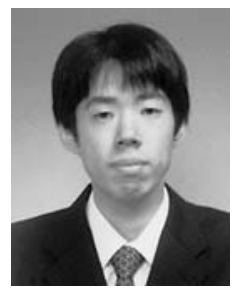
海大学第二工学部電気工学科通信工学専攻卒業。 2002 年 3 月同大大学院博士課程前期了。現在, 同 大大学院博士課程後期在学中。主としてディジタ ルネットワークおよびディジタル伝送方式 · 回路 に関する研究に従事。電子情報通信学会学生会員。

田中 公 男 (非会員) 1936 年 5 月 10 日生。 1959 年 3 月東京

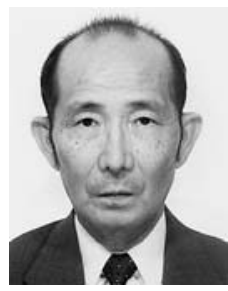
工業大学理工学部電気工学科卒業。同年日本電信 電話公社 (現, NTT) 電気通信研究所入所。1994 年 4 月東海大学第二工学部電気工学科教授。2001 年 4 月同大電子情報学部コミュニケーション工学 科教授。工学博士。主として回路理論, ディジタ ル伝送方式·回路およびディジタルネットワーク に関する研究に従事。電子情報通信学会会員。 